\title{
LEMBAGA KOMUNITAS LOKAL (STUDI TENTANG PERANNYA DALAM PEMBERDAYAAN MASYARAKAT KELURAHAN DI KOTA SEMARANG 2016)
}

\author{
Suharto \\ Dosen FISIP Universitas Wahid Hasyim Semarang
}

\begin{abstract}
Institutional Local Communities are local community institutions that are built and strengthened according to the needs of the community in a process of social transformation that is rooted, acknowledged and accepted by the community. The role of local community institutions in community empowerment is one of them participate in poverty reduction program which includes all activities of empowerment of village / village community. In the empowerment of the community the main target is the powerless community (poor) in the broadest sense and in fact most of the poor are urban community. In the community empowerment program has always been encouraged to be more pro poor and give more opportunities to the role of the community in community empowerment, especially the poor in Kelurahan. The existence of local community institutions in accordance with the interests and needs of these communities can be a driver of social capital for the process of social transformation from the condition of a powerless society into a powerless society, self-reliant and civil society who aspired together. The role of local community institutions BKM, LPMK and PKK community empowerment Muktiharjo Kidul Urban Village that all institutions participate in poverty alleviation urban village community and the role of each local community institutions in doing every community empowerment activities of the village tend to support and try with the aim that the community more empowered, independent and prosperous.
\end{abstract}

\section{Keywords: Local Community Institution, Community Empowerment}

\section{A. Pendahuluan}

Pada periode Maret 2014 Jumlah penduduk miskin di Jawa Tengah sebanyak 4,836 juta orang $(14,46 \%)$, mengalami kenaikan sebanyak 25,11 ribu orang (0,02\%) dibandingkan periode September 2013 sebanyak 4.811 juta orang (14,44\%). Kenaikan kemiskinan berada di daerah perkotaan sebanyak 32,21 ribu orang, sedangkan di daerah perdesaan justru mengalami penurunan sebanyak 7,09 ribu orang. Distribusi jumlah penduduk miskin pada periode Maret 2013 sebagian besar berada di daerah perdesaan (59,78\%), menurun dibanding periode September 2013 (60,24\%). Capaian persentase penduduk miskin Jawa Tengah pada periode Maret 2014 sebesar 14,46\% ini masih berada di atas Nasional 11,25\%. 
Berdasarkan basis data terpadu PPLS 2011, saat ini di Jawa Tengah terdapat 50 kecamatan (di 15 kabupaten) dengan tingkat kemiskinan tinggi, 234 kecamatan (di 27 kabupaten) dengan tingkat kemiskinan sedang, dan 289 kecamatan (di 30 kabupaten/kota). Dari total 8.578 desa/kelurahan di Jawa Tengah, terdapat 1.479 desa/kelurahan (terdiri dari 1.356 desa dan 123 kelurahan) masuk kategori tingkat kemiskinan tinggi, 2.235 desa/kelurahan (terdiri dari 2.080 desa dan 155 kelurahan) masuk kategori tingkat kemiskinan sedang, dan 4.864 desa/kelurahan (terdiri dari 4.373 desa dan 491 kelurahan) masuk kategori tingkat kemiskinan rendah. (sumber : paparan Kepala Bappeda Jateng pada workshop Peningkatan Peran Daerah dalam Penanggulangan Kemiskinan, Semarang 26 Agustus 2014).

Dalam kaitannya dengan peran kelembagaan komunitas lokal dalam pemberdayaan masyarakat yaitu berpartisipasi dalam penanggulangan kemiskinan, maka perlu untuk mengetahui bagaimanakah perannya dari setiap lembaga komunitas lokal dalam melakukan kegiatan pemberdayaan masyarakat kelurahan. Karena dalam pemberdayaan masyarakat, sasaran utama adalah masyarakat yang tidak berdaya (miskin) dalam arti luas dan secara nyata sebagian besar yang miskin adalah daerah perkotaan. Kelembagaan Komunitas Lokal merupakan lembaga masyarakat lokal yang dibangun dan diperkuat sesuai kebutuhan masyarakat dalam proses transformasi sosial yang mengakar, diakui dan diterima masyarakat.

Maka dalam program pemberdayaan masyarakat selalu didorong untuk pro poor dan lebih memberikan peluang yang besar terhadap peran masyarakat dalam pemberdayaan masyarakat khususnya masyarakat miskin di Kelurahan. Secara umum pemberdayaan masyarakat merupakan upaya untuk memulihkan atau meningkatkan keberdayaan suatu komunitas untuk mampu berbuat sesuai dengan harkat dan martabat mereka dalam melaksanakan hak-hak dan tanggung jawab mereka sebagai komunitas manusia \& warga Negara. Untuk dapat memulihkan kembali harkat dan martabat komunitas (warga miskin), pentingnya peran dari kelembagaan komunitas lokal dalam pemberdayaan masyarakat yang menjadi pola pendekatan program penanggulangan kemiskinan yang sekarang baru gencar-gencarnya digalakkan Pemerintah.

Dengan demikian untuk mengetahui sejauhmana peran kelembagaaan komunitas lokal dalam pemberdayaan masyarakat kelurahan, maka dilakukan penelitian kasus peran dari kelembagaan komunitas lokal yaitu LPMK, BKM, PKK dalam pemberdayaan masyarakat kelurahan Muktiharjo Kidul Kecamatan Pedurungan di Kota Semarang Provinsi Jawa Tengah.

\section{B. Kelembagaan Komunitas Lokal Dan Pemberdayaan Masyarakat}

Ada berbagai definisi kelembagaan yang disampaikan oleh beberapa ahli dari berbagai bidang. Menurut Ruttan dan Hayami, (1984) Lembaga adalah aturan di dalam suatu kelompok masyarakat atau 
organisasi yang menfasilitasi koordinasi antar anggotanya untuk membantu mereka dengan harapan di mana setiap orang dapat bekerja sama atau berhubungan satu dengan yang lain untuk mencapai tujuan bersama yang diinginkan. Sedangkan menurut Ostrom, (1985-1986) kelembagaan diidentikan dengan aturan dan rambu-rambu sebagai panduan yang dipakai oleh para anggota suatu kelompok masyarakat untuk mengatur hubungan yang saling mengikat atau saling tergantung satu sama lain. Penataan institusi (institusional arragements dapat ditentukan oleh beberapa unsur-unsur aturan operasional untuk mengatur pemanfaatan sumber daya, aturan kolektif untuk menentukan menegakkan hukum atau aturan itu sendiri dan untuk merubah aturan operasional serta mengatur hubungan kewenangan organisasi.

Sedangkan Pusat Bahasa, Kamus Besar Bahasa Indonesia (1997) kelembagaan didefinisikan sebagai suatu sistem badan sosial atau organisasi yang melakukan suatu usaha untuk mencapai tujuan tertentu. Dengan demikian kelembagaan adalah sebagai suatu tatanan dan pola hubungan antara anggota masyarakat atau organisasi yang saling mengikat yang dapat menentukan bentuk hubungan antar manusia atau antar organisasi yang diwadahi dalam suatu organisasi atau jaringan dan ditentukan oleh faktor-faktor pembatas dan pengikat berupa norma, kode etik atauran formal maupun informal untuk pengendalian perilaku sosial serta insentif untuk bekerjasama dan mencapai tujuan bersama.

Pada umumnya Lembaga dapat dibedakan menjadi dua jenis, yaitu lembaga formal dan lembaga non-formal. Sedangkan menurut Sitti Bulkis (2011), Kelembagaan lokal dan area aktivitasnya terbagi menjadi tiga kategori, yaitu kategori sektor publik (administrasi lokal dan pemerintah lokal); kategori sektor sukarela (organisasi keanggotaan dan koperasi); kategori sektor swasta (organisasi jasa dan bisnis swasta). Bentuk resmi suatu lembaga yaitu lembaga garis (line organization, military organization) lembaga garis dan staf (line and staff organization); lembaga fungsi (functional organization). Jadi pengertian dari kelembagaan adalah suatu sistem sosial yang melakukan usaha untuk mencapai tujuan tertentu yang menfokuskan pada perilaku dengan nilai, norma, dan aturan yang mengikutinya, serta memiliki bentuk dan area aktivitas tempat berlangsungnya.

Untuk mengetahui lebih rinci dasar hukum pembentukan lembga kemasyarakatan yang berada di kelurahan dapat dilihat dalam skema berikut : 


\section{LANDASAN HUKUM PEMBENTUKAN LEMBAGA KEMASYARAKATAN :}

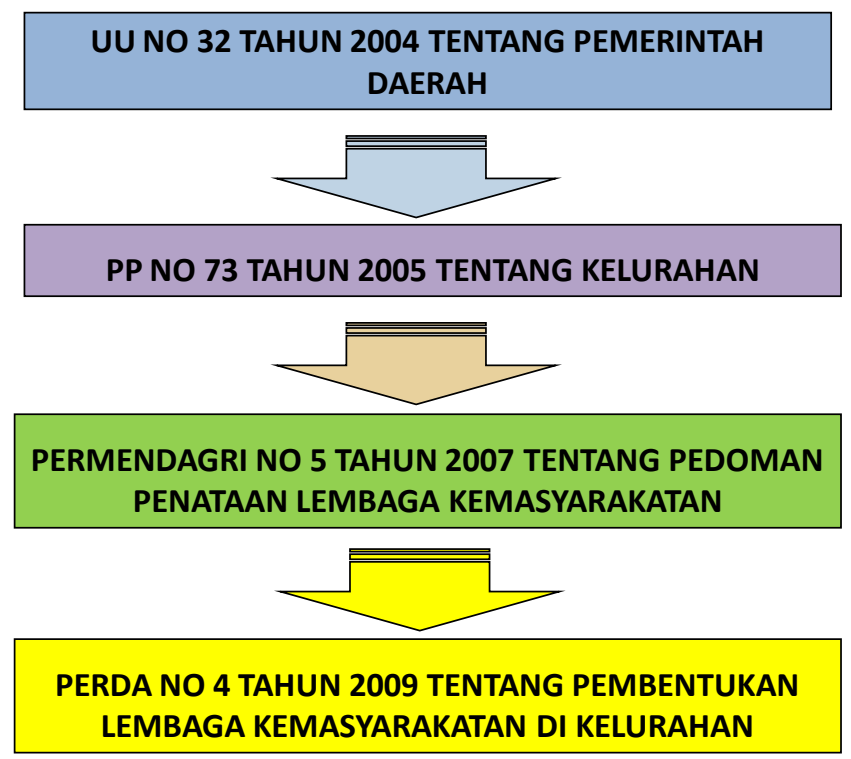

Kelembagaan Komunitas Lokal merupakan lembaga masyarakat lokal yang dibangun dan diperkuat sesuai kebutuhan masyarakat dalam proses transformasi sosial yang mengakar, diakui dan diterima masyarakat. Banyak lembaga komunitas lokal yang telah dibangun dan diperkuat sesuai kebutuhan masyarakat misalnya seperti BPD dan LKMD khusus di Desa, sedangkan LPMK di Kelurahan, dan PKK serta BKM di Desa maupun di Kelurahan. Lembaga ini diharapkan mencerminkan representasi dari seluruh masyarakat warga yang paling dapat dipercaya. Lembaga komunitas lokal diharapkan pula menjadi lembaga yang peduli terhadap kemiskinan dan kesejahteraan dikomunitasnya yang dipercaya oleh masyarakat untuk berpartisipasi dalam penanggulangan kemiskinan.

Berdasarkan Permendagri Nomor 5 tahun 2007 Tentang Pedoman Penataan Lembaga Kemasyarakatan: Pasal 2 ayat 1, 2 dan 4 : 1) Di Desa dan di Kelurahan Dapat dibentuk Lembaga Kemasyarakatan, 2) Pembentukan Lembaga Kemasyarakatan dilakukan atas prakarsa masyarakat dan/atau atas prakarsa masyarakat yang difasilitasi Pemerintah melalui musyawarah dan mufakat, 4) Pembentukan Lembaga Kemasyarakatan Kelurahan ditetapkan dalam Peraturan Daerah Kabupaten/Kota

Adapun kelembagaan kemasyarkatan yang dimaksud Permendagri Nomor 5 tahun 2007 Pasal 2 ayat 1, 2 dan 4 adalah : LPMK / LKMD atau sebutan lain, Lembaga Adat, TP. PKK Kelurahan, RT/RW, Karang Taruna, Lembaga Kemasyarakatan lainnya ( dalam hal ini termasuk BKM ). Dan 
berdasarkan Perda Nomor 4 tahun 2009 Tentang Pembentukan Lembaga Kemasyarakatan di Kelurahan: Pasal 2 ayat 1, 3 dan 4 : 1) Di Kelurahan Dapat dibentuk Lembaga Kemasyarakatan, 3) Pembentukan Lembaga Kemasyarakatan dapat dibentuk atas prakarsa masyarakat dan/atau atas prakarsa masyarakat yang difasilitasi Pemerintah Daerah melalui musyawarah dan mufakat, 4) Hasil Pembentukan Lembaga Kemasyarakatan Kelurahan ditetapkan dengan Keputusan Lurah.

Adapun yang dimaksud kelembagaan dalam Perda Nomor 4 tahun 2009 Tentang Pembentukan Lembaga Kemasyarakatan di Kelurahan: Pasal 2 ayat 1, 3 dan 4 yaitu RT, RW, TP. PKK, LPMK dan Karang Taruna. Lembaga Pemberdayaan Masyarakat Kelurahan (LPMK) dalam PP No 73 Tahun 2005 dijelaskan bahwa LPMK merupakan lembaga yang menampung dan menyalurkan aspirasi masyarakat, menggerakkan prakarsa dan partisipasi serta swadaya gotong royong dalam meningkatkan peran serta masyarakat dalam pembangunan. LPMK adalah lembaga penyusun rencana, pelaksana dan pengelola pembangunan serta pelestarian dan pengembangan hasil pembangunan secara partisipatif.

Badan Keswadayaan Masyarakat (BKM) dalam Pedoman Umum dan Pedoman Teknis PNPM P2KP (PNPM Mandiri Perkotaan 2010), merupakan nama generic dari suatu lembaga pimpinan kolektif masyarakat warga ditingkat Kelurahan atau Desa, yang diprakarsai serta dikelola secara mandiri oleh masyarakat warga dalam upaya memenuhi kebutuhan/kepentingan bersama, memecahkan persoalan bersama, dan menyatakan kepedulian bersama dengan berbasis nilai-nilai luhur kemanusiaan (ikhlas, jujur dan adil). Melakukan perencanaan partisipatif yang menghasilkan dokumen PJM Pronangkis (Program Jangka Menengah-Program PenangulanganKemiskinan) Kelurahan / Desa yang menjadi pedoman dalam pemberdayaan masyarakat Desa/ Kelurahan menjadi masyarakat yang berdaya, mandiri dan madani.

Pemberdayaan Kesejahteraan Keluarga (PKK) sesuai dengan Keputusan Mendagri No. 411.4401 Tahun 2005 bahwa PKK merupakan lembaga yang memberdayakan keluarga untuk meningkatkan kesejahteraan dengan merencanakan, melaksanakan, dan membina potensi masyarakat, hidup sehat dan kegiatan ekonomi produktif melalui 10 program pokok PKK. Pada dasarnya PKK ikut berpartisipasi dalam pelaksanaan program yang berkaitan dengan pemberdayaan dan kesejahteraan keluarga di Desa / Kelurahan.

Pada dasarnya lembaga komunitas lokal mempunyai fungsi dalam pemberdayaan masyarakat lokal yaitu antara lain : pertama, mendorong peran serta masyarakat dalam proses pengambilan keputusan sehingga masyarakat mengalami proses transformasi atau perubahan dalam kapasitasnya (skill, awareness, knowledge) dalam merencanakan, melaksanakan dan melestarikan hasil program / 
kegiatan di masyarakat. Selain itu ada kecenderungan perubahan tingkat partisipasi masyarakat dalam kegiatan-kegiatan di lingkungan atau ditingkat kelurahan. Kedua, mendukung program penanggulangan kemiskinan untuk mewujudkan keberdayaan atau kesejahteraan masyarakat dengan bersinergi dan berkoordinasi dengan lembaga komunitas lainnya maupun lembaga formil yang ada sehingga kesejahteraan masyarakat tercapai dengan cepat. Ketiga, menanamkan tingkat kepercayaan kepada nasyarakat, dengan hal ini akan mampu menggerakkan kekuatan swadaya masyarakat dan menjadi kekuatan dalam membangkitkan semangat pembangunan masyarakat lokal.

Pemberdayaan di tingkat komunitas lokal juga meliputi hal-hal sebagai berikut : 1) Proses pengembangan hubungan yang lebih setara, adil, dan tanpa dominasi di suatu komunitas. Pemberdayaan memerlukan proses penyadaran kritis masyarakat tentang hak-hak dan kewajibannya. Pemberdayaan juga memerlukan proses pengembangan kepemimpinan lokal yang egaliter dan memiliki legitimasi pada rakyatnya. 2) Proses untuk memberi daya/kekuasaan (power) kepada pihak yang lemah, dan mengurangi kekuasaan (disempower) kepada pihak yang terlalu berkuasa sehingga terjadi keseimbangan. 3) Membutuhkan pembagian kekuasaan (power sharing) antara kepemimpinan lokal dengan masyarakat secara adil. Pembagian kekuasaan yang adil berarti adalah penyelenggaraan sistem demokrasi di tataran komunitas (community democracy). Paling tidak itu yang saat ini dipercaya oleh gerakan demokrasi di seluruh dunia.

Dalam wacana pembangunan, terminologi peran atau peran serta ( partisipasi ) sangat melekat dengan terminologi pemberdayaan masyarakat, pengembangan partisipasi berarti dengan sendirinya adalah proses pemberdayaan, atau pengembangan partisipasi harus disertai dengan proses pemberdayaan. Dalam kenyataannya, pengembangan partisipasi tidak selalu demokratisasi, karena ada jenis-jenis partisipasi yang bersifat teknis/instrumental. Karena itu, partisipasi teknis tidak dapat dihubungkan dengan pemberdayaan karena proses pemberdayaan jelas tidak akan terjadi tanpa adanya agenda demokratisasi komunitas. Sebab, pengembangan partisipasi bisa saja dijalankan tanpa pemberdayaan. Partisipasi juga tidak selalu mendorong proses pemberdayaan. Sama seperti konsep partisipasi, konsep pemberdayaan seringkali dikebiri pemaknaannya menjadi teknis. Pembedayaan seringkali diartikan sebagai peningkatan kemampuan (bahkan keterampilan) masyarakat yang tidak dalam konteks perubahan komunitas dan demokratisasi.

Oleh karena itu peran Lembaga-lembaga komuninas sebagai pengembang program pembangunan juga meliputi peran sebagai pengorganisir rakyat (community organizer) karena partisipasi warga harus dikembangkan melalui penguatan lembaga-lembaga masyarakat/rakyat (organisasi sipil) yang bisa menjadi kelompok kepentingan dan kelompok penekan tingkat lokal dan mempengaruhi kebijakan-kebijakan (mempengaruhi lembaga politik formal melalui legislatif dan eksekutif lokal). Penguatan kelembagaan masyarakat (organisasi sipil lokal) ini, diperlukan dalam 
menopang pemerintahan lokal yang partisipatif (participatory local governance) atau komunitas yang demokratis (demokratic community).

Pemberdayaan (empowerment) adalah sebuah konsep yang berhubungan dengan 'kekuasaan' (power). Dalam tulisan Robert Chambers (1995), kekuasaan (power) diartikan sebagai kontrol terhadap berbagai sumber kekuasaan, termasuk ilmu pengetahuan dan informasi. Karena itu, pemikiran penting Chambers mengenai pemberdayaan masyarakat adalah pengambilalihan penguasaan terhadap ilmu pengetahuan dan informasi, sebagai salah satu sumber kekuasaan yang penting, dari orang luar (peneliti dan agen pembangunan) oleh masyarakat. Caranya dengan menggali dan menghargai pengetahuan dan teknologi lokal, serta menjadikan proses pembelajaran sebagai milik masyarakat, bukan milik orang luar. Selain itu, Chambers juga melihat isu kekuasaan dalam konteks pola hubungan antara kelompok dominan/elite masyarakat dengan kelompok 'bawah', antara negaranegara miskin (dalam skala komunitas, nasional maupun global).

Pemberdayaan (empowerment) dalah suatu proses untuk memberikan daya/ kekuasaan (power) kepada fihak yang lemah (powerless) dan mengurangi kekuasaan (disempowered) kepada fihak yang terlalu berkuasa (powerfull) sehingga terjadi keseimbangan (Djohani,2003). Begitu pula menurut Rappaport (1984) pemberdayaan adalah suatu cara dengan mana rakyat, organisasi dan komunitas diarahkan agar mampu menguasai atau berkuasa atas kehidupannya.

Menurut Parsons (1994) pemberdayaan menekankan bahwa orang memperoleh keterampilan, pengetahuan, dan kekuasaan yang cukup untuk mempengaruhi kehidupannya dan kehidupan orang lain yang menjadi perhatiannya. Kekuasaan dalam konteks politik adalah kemampuan untuk mempengaruhi dan mengatur kehidupan warga (rakyat). Kekuasaan politik harus dibatasi dengan membangun sistem demokrasi. Karena itu, salah satu prinsip dasar demokrasi adalah tersedianya ruang partisipasi warga yang mampu mengontrol penyalahgunaan kekuasaan oleh pemimpin yang diberi mandat oleh warga. Jadi, kekuasaan sebenarnya adalah milik rakyat, tetapi yang terjadi kemudian adalah pengambilalihan kekuasaan oleh elite politik karena belum/tidak berfungsinya sistem pemerintahan yang mungkin ditegakkannya kedaulatan rakyat. Hal ini terjadi karena rakyat belum mampu melindungi kekuasaannya. Sedangkan, pemimpin politik, cenderung untuk tidak bersedia membatasi kekuasaannya, bahkan lebih suka memperbesar kekuasaan tersebut.

Pemberdayaan memerlukan proses penyadaran kritis masyarakat tentang hak-hak dan kewajibannya. Pemberdayaan juga memerlukan proses pengembangan kepemimpinan lokal yang egaliter dan memiliki legitimasi pada rakyatnya. Proses untuk memberi daya/kekuasaan (power) kepada pihak yang lemah, dan mengurangi kekuasaan (disempower) kepada pihak yang terlalu berkuasa sehingga terjadi keseimbangan. Dalam kaitannya dengan pemberdayaan masyarakat perlu adanya kesamaan pandang untuk konsep pengertian ini. Karena dalam pemberdayaan masyarakat jelas 
sasaran utama adalah masyarakat yang tidak berdaya (miskin) dalam arti luas dan secara nyata sebagian besar yang miskin adalah di perkotaan (kantong kemiskinan). Maka dalam program pemberdayaan masyarakat (penanggulangan kemiskinan) selalu didorong untuk pro poor dan lebih memberikan peluang yang besar terhadap peran kelembagaan komunitas lokal.

Secara umum pemberdayaan masyarakat merupakan upaya untuk memulihkan atau meningkatkan keberdayaan suatu komunitas untuk mampu berbuat sesuai dengan harkat dan martabat mereka dalam melaksanakan hak-hak dan tanggung jawab mereka sebagai komunitas manusia \& warga Negara. Untuk dapat memulihkan kembali harkat dan martabat komunitas (warga miskin / belum berdaya) perlu adanya pemberdayaan masyarakat salah satunya antara lain program penanggulangan kemiskinan yang sekarang baru gencar-gencarnya digalakkan Pemerintah.

Dengan mengetahui informasi tersebut dapat diukur sampai sejauh mana program kegiatan yang dilaksanakan lembaga komunitas local khususnya telah melibatkan seluruh komponen 'masyarakat lokal' secara aktif dalam pengambilan keputusan, pelaksanaannya maupun pelestariannya. Kecenderungan yang sering terjadi adalah program-program kegiatan/pembangunan yang ada di masyarakat kurang melihat keterlibatan masyarakat secara aktif dan masyarakat berperan serta dalam program hanya seremonial saja sehingga program tersebut kurang optimal dalam pemberdayaan masyarakat sehingga pelestarian pasca program juga kurang berjalan.

Maka pola pendekatan pemberdayaan masyarakat sangat mementingkan partisipasi aktif masyarakat dalam setiap kegiatan dan masyarakat sasaran selalu diposisikan sebagai pelaku utama (subjek) sekaligus sebagai sasaran program (objek). Sehingga pelibatan dari proses perencanaan, pelaksanaan, pelestariannya dan bahkan di dukung oleh kelembagaan komunitas lokal yang ada ( LPMK, BKM , PKK dll) akan berhasil optimal dengan tercapainya masyarakat berdaya yaitu kesejahteraan masyarakat kelurahan.

Dengan melihat konsep-konsep diatas maka peran kelembagaan komunitas lokal dalam pemberdayaan masyarakat di Kelurahan mempunyai posisi yang sangat strategis dan juga menjadi salah satu motor penggerak partisipasi masyarakat dan pelaku dari pemberdayaan masyarakat yang efektif. Pemberdayaan masyarakat merupakan pola pendekatan pembangunan yang telah disepakati secara nasional dan mempunyai tujuan akhir yaitu untuk mewujudkan masyarakat sejahtera yang berdaya, mandiri dan madani. Hal ini keberhasilannya juga ditentukan oleh peran serta kelembagaan komunitas lokal yang berkegiatan di masyarakat. Hal ini perlu dibuktikan bahwa semakin meningkat keberdayaan masyarakat di kelurahan (perkotaan) karena salah satunya ada peran kelembagaan komunitas lokal dalam berusaha untuk menaikkan daya ekonomi keluarga mereka dari belum berdaya (miskin) menjadi berdaya (sejahtera), daya sosialnya dan daya lingkungannya (infrastruktur). 


\section{Peran Kelembagaan Komunitas Lokal Dalam Pemberdayaan Masyarakat Kelurahan Muktiharjo Kidul Kec.Pedurungan Kota Semarang.}

Kelurahan Muktiharjo Kidul termasuk wilayah Kecamatan Pedurungan dengan batas- batas sebagai berikut : Sebelah Utara : Kelurahan Muktiharjo Lor Kecamatan Genuk, Sebelah Selatan : Kelurahan Tlogosari Kulon Kecamatan Pedurungan, Sebelah Timur : Kelurahan Tlogosari Wetan Kecamatan Pedurungan dan Sebelah Barat : Kelurahan Kaligawe Kecamatan Gayamsari. Jarak dari Kelurahan Muktiharjo Kidul ke ibukota kecamatan sekitar $2 \mathrm{~km}$ dengan waktu tempuh perjalanan dengan motor kurang lebih 20 menit.

Kecamatan Pedurungan terdiri dari 1.128 Rukun Tetangga (RT) dan 154 Rukun Warga (RW) yang terhimpun dalam 37.294 Kepala Keluarga. Sampai dengan bulan Mei 2014 wilayah yang paling padat penduduknya adalah Kelurahan Tlogosari Kulon sebesar35.716 jiwa dan yang paling rendah jumlah penduduknya adalah Kelurahan Penggaron Kidul sebesar 5.597 jiwa.

\section{C.1. Peran Kelembagaan BKM ( Badan Keswadayaan Masyarakat ).}

Pada dasarnya BKM mempunyai peran menghimpun, menyerap, mengelola aspirasi masyarakat umum kelurahan melalui rembug warga berbasis partisipasi aktif dalam penanganan program penanggulangan kemiskinan menuju masyarakat mandiri, sejahtera dan berdaya melalui program pemberdayaan masyarakat yang ada dan kegiatan program kebijakan Pemerintah Kota/Kelurahan. Pengembangan, pengokohan dan pemampuan kelembagaan yang dilakukan dapat dilihat dari indikator, kemampuan BKM dalam menubuhkan kerjasama dan kepercayaan di internal BKM, kemampuan BKM untuk menumbuhkan kerjasama dan kepercayaan antara BKM dengan Masyarakat atau eksternal BKM, kemampuan BKM untuk memotivasi warga dalam melakukan pembangunan (peran BKM sebagai Agent of social change) kemampuan BKM dalam menjalin kemitraan dengan pihak luar.

Hubungan BKM dengan masyarakat, juga menjadi acuan dalam melihat keamfaatan dalam pengembangan, pengokohan dan pemampuan kelembagaan. Dengan adanya kegiatan maupun kepercayaan yang diberikan masyarakat kepada BKM, maka berimplikasi pada terwujudnya gerakan penanggulangan kemiskinan yang diinisasi oleh BKM dan masyarakat setempat.

Menurut masyarakat, dari beberapa indikator menunjukkan hasil yang cukup baik yaitu seperti kemampuan BKM dalam menjalankan kegiatan pemberdayaan dan penanggulangan kemiskinan, cara penyajian informasi dan pelaksanaan pengawasan bersama yang dilakukan masyarakat, tingkat keterlibatan masyarakat dalam kegiatan BKM, serta tingkat kepercayaan atau akuntabilitas yang dimiliki BKM kepada masyarakat juga dilakukan cukup baik. 
Adapun mengenai kemampuan BKM dalam menjalankan kegiatan pemberdayaan dan pembangunan di masyarakat, menunjukan, bahwa 57\% menyatakan BKM cukup mampu, dan 34\% menyatakan sangat mampu sedangkan 6\% menyatakan kurang mampu dan tidak mampu. Hal ini menunjukkan sebagian besar BKM cukup mampu melakukannya.

\section{Diagram}

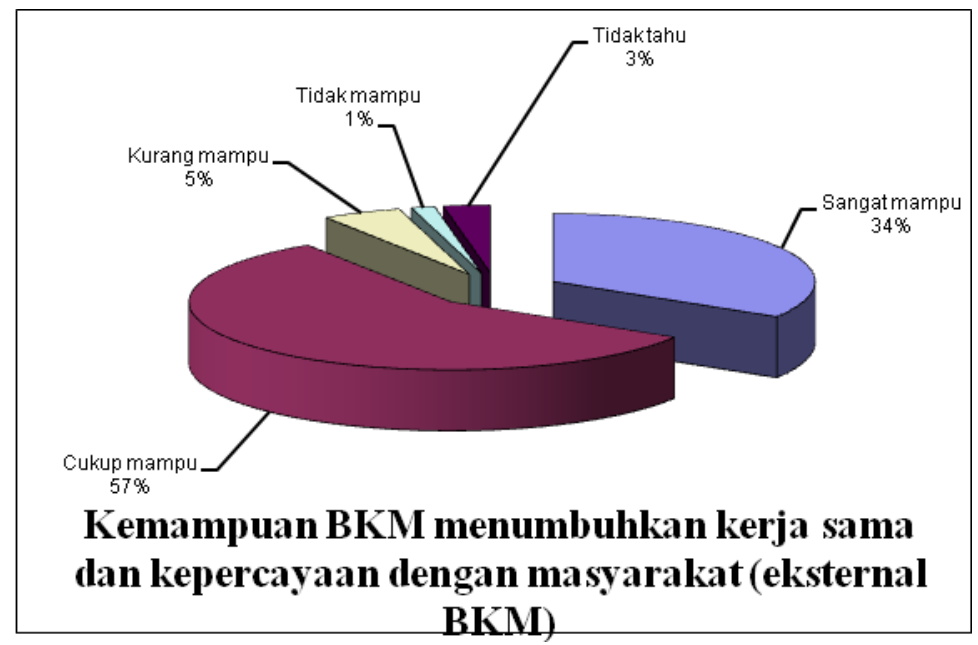

Kegiatan yang paling sering diikuti masyarakat dalam kegiatan yang diselenggarakan BKM, yang paling banyak adalah pinjaman bergulir KSM, sekitar 28\%, pembangunan sarana prasarana dasar lingkungan sebesar 11\%, sosialisasi kegiatan BKM adalah 16\%, rapat warga tahunan adalah 19\%, kegiatan sosial BKM, pemilihan anggota BKM adalah 9\% dan sisanya $4 \%$ adalah pelaksanaan perencanaan partisipatif.

\section{Diagram}

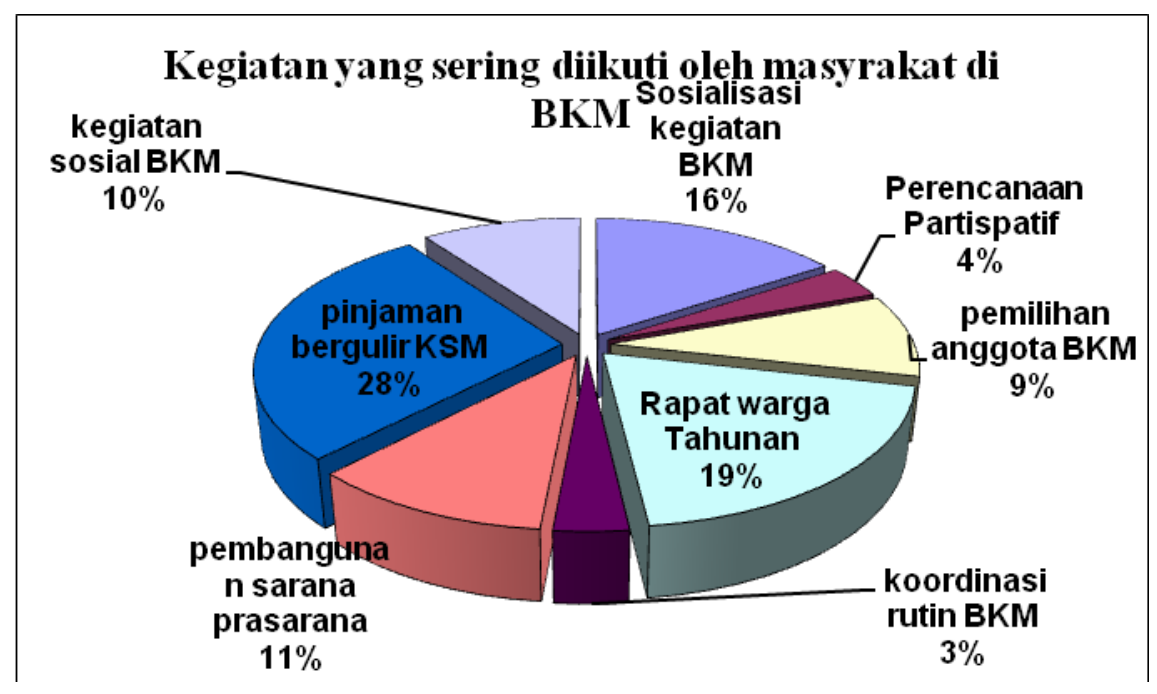


Faktor yang paling banyak mempengaruhi masyarakat dalam kegiatan BKM sebagian besar responden masih belum mempunyai tingkat kesadaran yang cukup tinggi. Faktor yang paling banyak mempengaruhi keterlibatan masyarakat dalam kegiatan BKM adalah karena motivasi untuk mendapatkan pinjaman adalah 32\%, sedangkan yang sadar untuk membantu orang miskin (27\%) dan atas kesadaran pribadi adalah 24\%, diundang pengurus BKM sebesar 11\%, karena sungkan sebesar 4\%. Tingginya motivasi atau faktor yang mempengaruhi keterlibatan masyarakat dalam kegiatan BKM karena ingin mendapatkan pinjaman, disebabkan oleh ada nya hubungan dengan tingginya keterlibatan masyarakat dalam kegiatan BKM untuk ekonomi bergulir KSM. Kegiatan yang populer di BKM dalam kegiatan masyarakat mempengaruhi motivasi masyarakat dalam terlibat kegiatan BKM.

Bantuan yang sering diberikan BKM kepada masyarakat dalam rangka meberikan stimulan pemberdayaan maupun pembangunan di masyarakat, adalah sebagian besar berupa pinjaman bergulir sebesar 62\%, pembangunan infrastruktur adalah 21\%, pelatihan masyarakat sebesar 10\% dan pemberian santunan sebesar $5 \%$.

\section{Diagram}

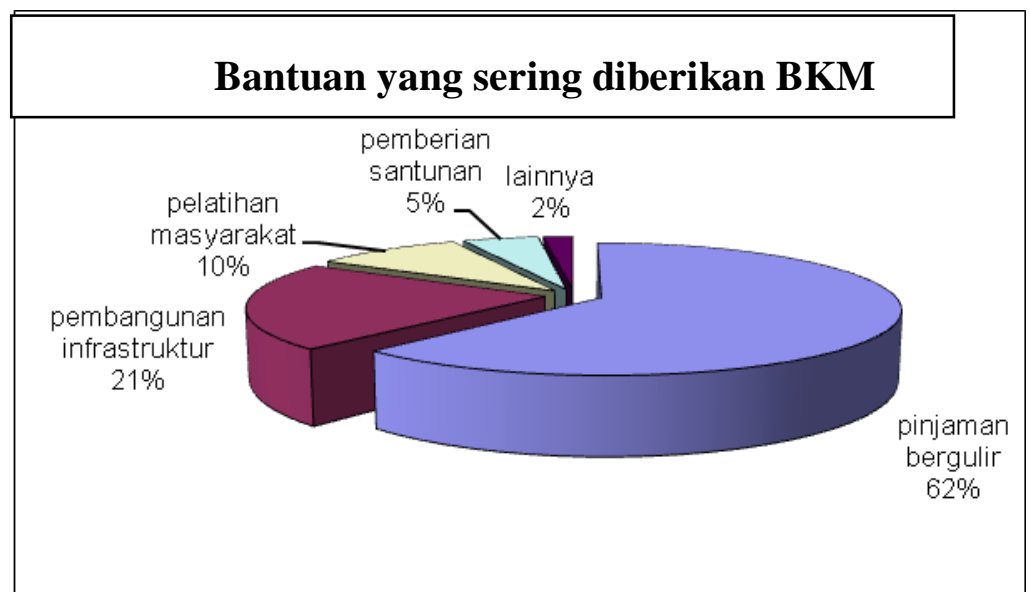

Dalam kegiatan BKM adalah rangkaian proses pembelajaran bagi masyarakat untuk melakukan kegiatan penanggulangan kemiskinan dengan memanfaatkan segenap potensi dan sumberdaya untuk memecahkan permasalahan yang muncul di masyarakat secara mandiri dan berkelanjutan. Penyadaran kritis dan pembelajaran untuk peningkatakan kapasitas dalam pembangunan di BKM, dilakukan secara bertahap dan berkesinambungan melaui dari kesepakatan bersama dalam Rembug kesiapan masyarakat, refleksi kemiskinan, perencanaan partispatif yang diwujudkan dalam PJM pronangkis, pelaskanaan kegiatan hingga pengawasan kegiatan secara partispatif secara bersama-sama yang dilakukan oleh masyarakat sendiri. Penyadaran kritis ini merupakan dasar dari pola pemberdayaan masyarakat, agar nantinya masyarakat mampu 
melaksanakan pembangunan sendiri tanpa harus bergantung terus dengan pemerintah, dan melaksanakan pembangunan sesuai dengan kebutuhan.

Dalam pelaksanaan pembangunan, sebagian besar masyarakat masih memberikan kontribusi yang belum riil atau signifikan dengan kata lain nilai swadayanya masih belum bisa diukur secara nyata, yaitu yang berbentuk tenaga, ide dan konsumsi saja. Hal ini tampak dari jawaban responden mengenai kontribusi yang diberikan dalam pelaksanaan pembangunan. Yang menjawab kontrbusi dalam bentuk tenaga saja sebesar $40 \%$, yang berbentuk ide saja sebesar $32 \%$, dan yang manjwab tenaga ide dan uang sebesar $21 \%$, yang meberikan kontribusi uang $5 \%$ dan yang memberikan asetnya untuk pembanguna sebesar $2 \%$, aset ini bisa berupa tanah yang diberikan untuk fasilitas umum atau barang pribadi yang dimiliki oleh masyarakat.

\section{Diagram}

\section{Kontribusi masyarakat dalam pelaksanaan pembangunan}

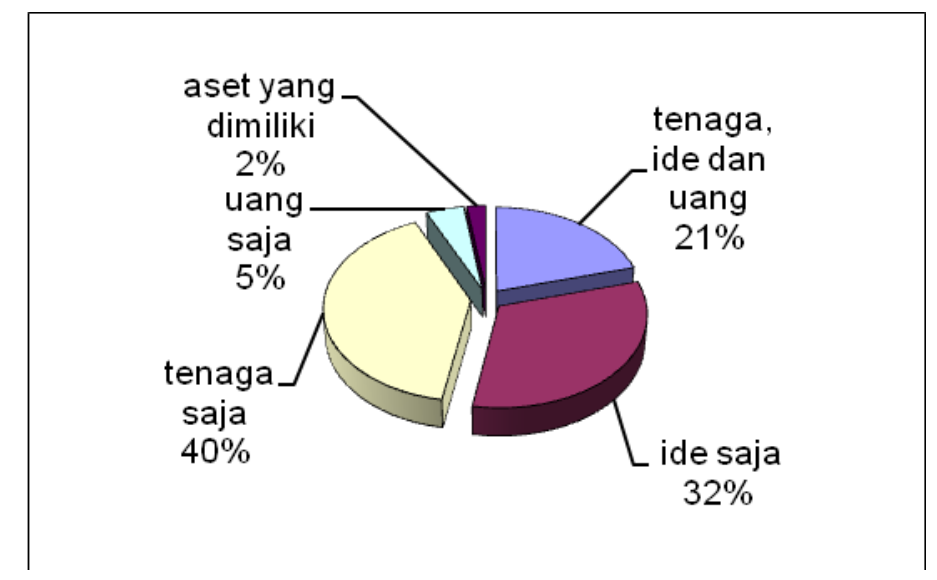

\section{C.2 Peran Kelembagaan LPMK (Lembaga Pemberdayaan Masyarakat Kelurahan) Kelurahan Muktiharjo Kidul Kecamatan Pedurungan Kota Semarang.}

LPMK (Lembaga Pemberdayaan Masyarakat Kelurahan) : adalah organisasi sosial yang mempunyai peran dan fungsi dalam meningkatkan / memperdayakan masyarakat dengan melalui lembaga RT/RW di wilayah kelurahan. Adapun Rukun Warga (RW) adalah suatu organisasi sosial kemasyarakatan yang menggerakan masyarakat di bidang sosial dalam wilayah rukun warga didalam kelurahan/desa. Tugas RW yaitu membantu pelayanan kepada warga, mengkoordinir kegiatan social kemasyarakatan ditingkat wilayah, menjalin kerjasama dengan lembaga social kemasyarakatan ditingkat kelurahan, membantu pemberdayaan potensi yang ada di wilayah. Menghimpun masyarakat warga dilingkungan masing-masing wilayah, menyelaraskan satu kesatuan diwilayah yang menjadi 
lingkup wilayah tersebut. RW juga sebagai alat atau perangkat wilayah yang membantu kepemerintahan dibawah kelurahan.

RW selama ini mengkoordinir wilayah meliputi RT, PKK, BKR, Posyandu, PAUD, Dasawisma, Karangtaruna, Lansia, Dawis. Melayani masyarakat surat menyurat kepemerintahan (surat pengantar untuk ke kelurahan, kecamatan, kepolisian dll). Membantu Kelurahan dalam ikut menata dan melaksanakan pembangunan dan pengembangan wilayah RW. Memberi ide dan wawasan untuk pengembangan wilayah. Melindungi dan mengawasi keamanan ketentraman dan keindahan lingkungan RW, Memberi masukan kepada pemerintah yang perlu untuk dikembangkan atau diberi bantuan untuk memandirikan masyarakat. Membantu fihak Kelurahan mencari cara untuk masyarakat lingkungan RW bisa maju ekonominya menjadi baik atau mandiri sejahtera.

Sedangkan Rukun Tetangga (RT) merupakan organisasi / lembaga sosial kemasyarakatan yang menggerakan kegiatan masyarakat yang paling bawah (grass roat) yaitu kegiatan masyarakat di lingkup rukun tetangga. Sebagai alat atau perangkat wilayah yang membantu kepengurusan dibawah RW setempat. RT juga merupakan sekelompok keluarga yang tergabung menjadi satu untuk meningkatkan kedamaian dan kemajuan masyarakat dalam bidang pembangunan dilingkungan rukun tetangga. Dan didalam RW dan RT ada kelompok Karang Taruna yaitu sekelompok pemuda-pemudi yang aktif dalam meningkatkan pengabdian kepada masyarakat terkait kegiatan kepemudaan dan pembangunan mental remaja misalnya gerakan anti narkoba dan menjahui dari unsur kenakalan remaja,

Lembaga Pemberdayaan Masyarakat Kelurahan (LPMK) dibentuk dalam rangka menciptakan dan meningkatkan partisipasi masyarakat dalam penyelenggaraan pemerintahan dan pembangunan, Lembaga pemerintah dan lembaga kemasyarakatan harus dapat saling bekerja sama agar tujuan pemerintahan dapat terealisasi dengan optimal. LPMK merupakan wadah yg dibentuk atas prakarsa masyarakat sebagai mitra pemerintah dalam menampung dan mewujudkan aspirasi dan partisipasi masyarakat di bidang pembangunan di lingkup wilayahnya.

LPMK merupakan sebuah lembaga yang bertugas memberdayakan masyarakat ditingkat kelurahan diberbagai bidang. LPMK membantu kelurahan dalam memajukan masyarakat kelurahan, memberdayakan SDM ditingkat kelurahan, membuat pemetakan demografi social dan kerohanian tingkat kelurahan, menampung aspirasi masyarakat kelurahan melalui RW, membantu Pemerintah Kelurahan mencari solusi/ pemecahan masalah yang berkembang dimasyarakat kelurahan, mencakup stabilitas politik, ekonomi, social, budaya \& keamanan. LPMK sebagai sarana wadah pemersatu dari RT dan RW diwilayah Kelurahan, sebagai ujung rembug masyarakat dan sebagai mitra Lurah dalam melaksanakan tugas melayani masyarakat. 
Menurut Perda Nomor 4 tahun 2009 tentang Lembaga Kemasyarakatan Kelurahan Kota Semarang, Bab I pasal 1 butir 10 yaitu : "Lembaga Pemberdayaan Masyarakat Kelurahan ( LPMK ) adalah Lembaga Kemasyarakatan yang dibentuk warga Kelurahan yang bersangkutan untuk membantu Kelurahan dalam perencanaan dan pelaksanaan pembangunan serta menumbuh kembangkan swadaya masyarakat dalam pembangunan"

Adapun Tugas LPMK menurut pasal 10 Perda no 4 th 2009 yaitu :

LPMK mempunyai tugas : 1) Menyusun rencana pembangunan secara partisipatif, 2) Menggerakkan swadaya gotong royong masyarakat, 3) Melaksanakan dan mengendalikan pembangunan. Sedangkan kondisi LPMK Kelurahan Muktiharjo Kidul apabila dilihat dari tugasnya daam Perda No 4 tahun 2009 tersebut menunjukkan perannya masih memprihatinkan dan juga belum optimal dalam tata kelola kepengurusan dan masih belum menunjukkan LPMK yang berdaya dan mandiri dalam mengemban 3 (tiga) tugas fungsinya sebagai lembaga pemberdayaan masyarakat kelurahan. Hasil penelitian menunjukkan bahwa peran LPMK Kelurahan Muktiharjo kidul kurang adanya ada pembagian tugas dengan pengurus lain sesuai tugas bidangnya masing-masing, seperti Bendahara tahu tentang tugasnya tetapi tidak diberi peran maksimal oleh Ketua. Demikian pula dalam hal pencairan dana LPMK, Bendahara tidak tahu dan tidak diajak oleh Ketua, yang seharusnya yang mencairkan adalah Ketua dan Bendahara LPMK. Kenyataannya Bendahara hanya diberi uang sisa yang sudah digunakan oleh Ketua dan pihak Kelurahan. Dan yang sangat memprihatinkan kapan menerima dana terakhir untuk tahun 2016 tidak tahu dan juga belum membuat laporan tahun 2016.

Untuk penggunaan dana LPMK bantuan APBD, selama ini hanya untuk tranport Ketua, kerja bakti, untuk rapat pengurus, bantuan panitia 17-an tingkat Kelurahan, bahkan untuk talangan membayar listrik Balai Kelurahan yang pernah nunggak 4 bulan (padahal Balai Kelurahan juga dapat penghasilan dari penggunaan untuk olah raga dan kadang-kadang dapat uang sewa untuk resepsi / mantu). Yang menjadi keprihatinan lagi penggunaan dana bantuan APBD hanya untuk manmin maksudnya sebagian besar makan minum. Dan tentang perencanaan penggunaan keuangan bantuan APBD tidak punya, yang seharusnya direncanakan dengan baik.

Untuk kegiatan rapat-rapat juga tidak ada rencana dengan jelas dan baik, hanya nunggu intruksi dari Ketua. Adapun pengurus / bidang-bidang di LPMK Kelurahan Muktiharjo Kidul tidak mendapatkan kucuran / alokasi dana untuk kegiatan bidang. Kondisi sekarangpun perencanaan penggunaan dana tahun 2017 juga belum ada pembahasan maupun dokumen perencanaannya. Seperti yang disampaikan pengurus, sebetulnya banyak yang ingin mengundurkan diri dengan kondisi 
kelembagaan LPMK yang masih belum optimal dari sisi capaian maupun kelembagannya. Tetapi mereka tetap bertahan karena tidak mau membiarkan hal yang tidak baik di kelembagaan LPMK dan ingin bersama memperbaiki keadaan LPMK.

Memperhatikan uraian tersebut bisa dimaknai bahwa pengelolaan LPMK Kelurahan Muktiharjo Kidul belum baik dan belum optimal, kepengurusan masih tersentral pada Ketua, dan kepengurusan belum dioptimalkan kinerjanya. Perencanaan kegiatan LPMK belum ada dan pengelolaan keuangan juga belum sesuai dengan tatakelola keuangan yang benar cenderung didominasi Ketua. Dan masih ada indikasi intervensi / campur tangan urusan pengelolaan kegiatan dan keuangan oleh pihak Kelurahan masih tinggi. Kondisi seperti ini kurang baik bagi LPMK ke depan, karena kurang memberdayakan semua pengurus dan juga dalam mencapai tugas yang diemban LPMK tidak bisa optimal membantu Kelurahan Muktiharjo Kidul dalam mensukseskan pembangunannya.

\section{C.3. Peran Kelembagaan PKK (Pemberdayaan Kesejahteraan Keluarga) Kelurahan Muktiharjo Kidul Kecamatan Pedurungan Kota Semarang.}

PKK merupakan organisasi wanita yang dikelola oleh ibu-ibu diwilayah RT, RW, maupun tingkat kelurahan terdiri dari : Ketua, Wakil ketua, Sekretaris, Bendahara, Pokja I s.d IV. PKK tingkat kelurahan mengkoordinir, Ibu-ibu pengurus PKK timgkat RW. PKK RW mempunyai tugas membantu dalam membuat rencana kerja dan menerima panduan atau acuan dari PKK Kelurahan dan Kecamatan dan melaksanakan program kerja yang sudah dibuat bersama. PKK Kelurahan melaksanakan petunjuk atau arahan dari tingkat Kecamatan dan Kota, dan disebarluaskan pada PKK untuk ditindaklanjuti pengurus PKK dan masyarakat bawah.

Hakekat pembangunan nasional adalah pembangunan manusia seutuhnya, yang akan terwujud apabila kesejahteraan keluarga dan masyarakat dapat dicapai dengan baik. Untuk mewujudkan kesejahteraan keluarga dan masyarakat upaya yang dapat dilakukan antara lain adalah dengan pemberdayaan masyarakat melalui gerakan pemberdayaan dan kesejahteraan keluarga (PKK). PKK bukanlah sekedar tempat arisan dan pengajian, tetapi merupakan wadah bagi pemberdayaan masyarakat.

Gerakan Pemberdayaan dan Kesejahteraan Keluarga selanjutnya disingkat PKK, adalah gerakan nasional dalam pembangunan masyarakat yang tumbuh dari bawah yang penelolaannya dari, oleh, dan untuk masyarakat menuju terwujudnya keluarga yang berimandan bertaqwa kepada Tuhan YME, berakhlak mulia dan berbudi luhur, sehat sejahtera, maju dan mandiri, kesetaraan dan kadian gender, serta kesadaran hukum dan lingkungan.

Penyelenggaraan pemberdayaan masyarakat melalui gerakan PKK Kelurahan Muktiharjo Kidul telah dilakukan melalui 10 (sepuluh) Program Pokok PKK, yaitu kegiatan Pengamalan 
Pancasila, Gotong Royong, Pangan, Sandang, Perumahan dan Tatalaksana Rumah Tangga, Pendidikan dan Keterampilan, Kesehatan, Pengembangan Kehidupan Berkoperasi, Kelestarian Lingkungan Lingkungan Hidup, dan Perencanaan Sehat. Sasaran Pemberdayaan Masyarakat melalui Gerakan PKK adalah keluarga, khususnya ibu rumah tangga, perempuan ditingkat Kelurahan, RW dan RT sebagai sosok sentral dalam keluarga, di perkotaan yang perlu ditingkatkan dan dikembangkan kemampuan mental spiritual dan fisik material nya.

Gerakan PKK dimulai dari tingkat pusat, provinsi, kabupaten/kota, kecamatan, hingga kelurahan dan desa. Untuk mempercepat pemberdayaan masyarakat melalui Gerakan PKK, Kepala Kelurahan membentuk kelompok pengurus PKK dusun/lingkungan/RW, RT dan kelompok Dasa Wisma. Strategi yang digunakan PKK untuk menjangkau sebanyak mungkin keluarga, adalah melalui kelompok Dasa Wisma tesebut.

Dasa Wisma terdiri dari Dasa dan Wisma. Secara harafiah pengertian Dasa artinya sepuluh dan Wisma artinya rumah atau tempat tinggal. Dasa Wisma adalah kelompok yang berada dibawah Tim Penggerak PKK RT, RW, Kelurahan, yang dapat dibentuk berdasarkan lingkup kewilayahan RT, dan terdiri dari 10 sampai 20 Kepala Keluarga (KK) dalam satu wilayah Rukun Tetangga (RT). Salah satu dari anggota keluarga pada kelompok persepuluh dipilih untuk dijadikan ketua kelompok atau penghubung dengan Pembina. Ketua kelompok Dasa Wisma membina 10 rumah dan mempunyai tugas menyuluh, menggerakkan dan mencatat kondisi keluarga yang ada dalam kelompoknya. Informasi dari semuanya ini harus disampaikan kepada ketua kelompok PKK setingkat diatasnya yang akhirnya sampai di Tim Penggerak PKK Kelurahan Muktiharjo Kidul. Adapun Tim Penggerak PKK Kelurahan berperan sebagai motivator, fasilitator, perencana, pelaksana, pengendali dan penggerak.

Dasa Wisma adalah kelompok terkecil dari kelompok-kelompok PKK menjadi ujung tombak pelaksanaan 10 program pokok PKK dan program-program pemerintah lainnya, dan karenanya memiliki peran strategis mewujudkan keluarga sejahtera. Dasa Wisma juga merupakan suatu organisasi kecil di tingkat masyarakat. Agar dapat mendukung keberhasilan pencapaian pelaksanaan progam-program PKK, perlu PKK Kelurahan Muktiharjo Kidul memberikan arah dan panduan bagi Dasa Wisma agar dapat mencapai tujuan dan sasaran Gerakan PKK tersebut dalam mewujudkan keluarga sejahtera.

Di dalam Undang-undang Dasar 1945 ditegaskan bahwa negara menjamin hak asasi manusia dalam berbagai bidang layanan dasar agar dapat hidup dan mempertahankan hidup dan kehidupannya. Negara juga mengembangkan sistem jaminan sosial bagi seluruh rakyat, dan memberdayakan masyarakat yang lemah dan tidak mampu sesuai dengan martabat kemanusiaan. Negara pun bertanggungjawab atas penyediaan fasilitas pelayanan kesehatan/gizi dan fasilitas pelayanan umum 
yang baik seperti pendidikan dan optimalisasi tumbuh kembang anak, pemberdayaan ekonomi keluarga, ketahanan pangan keluarga, dan kesejahteraan sosial.

Salah satu bentuk tanggungjawab Negara itu adalah dibangunnya Pos Pelayanan Terpadu (POSYANDU) dengan sistematika kerja antar-kementerian di tingkat pusat dan antar-dinas di tingkat daerah. Salah satu fungsi Posyandu adalah untuk peningkatan kualitas sumber daya manusia sejak dini melalui layanan sosial dasar masyarakat untuk menunjang pembangunan. Untuk menjalankan seluruh fungsi pelayanan publik itu diperlukan kelembagaan Posyandu yang mengintegrasikan berbagai layanan sosial dasar tersebut di atas. Sebagai sebuah kelembagaan, Posyandu dibangun dengan mempertimbangkan partisipasi masyarakat untuk meningkatkan kualitas kehidupan masyarakat dan lingkungannya.

Agar dapat mendukung keberhasilan pencapaian pelaksanaan progam-programnya Posyandu di wilayah Kelurahan Muktiharjo Kidul dilakukan kegiatan untuk mendorong dalam suatu Rencana Aksi. Rencana Aksi adalah suatu rencana kegiatan yang lebiih terperinci untuk meterjemahkan strategi dan arahan yang telah diindikasikan dalam rencana kegiatan Posyandu dari PKK tingkat Kelurahan RW dan RT, dan dijabarkan kedalam program-program atau kegiatan yang lebih operasional dilingkup Posyandu masing-masing.

\section{Kesimpulan}

Peran kelembagaan komunitas lokal BKM, LPMK dan PKK.dalam pemberdayaan masyarakat Kelurahan Muktiharjo Kidul yaitu salah satunya berpartisipasi dalam penanggulangan kemiskinan, dan perannya dari setiap lembaga komunitas lokal dalam melakukan kegiatan pemberdayaan masyarakat kelurahan agar masyarakat lebih mandiri dan sejahtera. BKM Kelurahan Muktiharjo Kidul mempunyai peran menghimpun, menyerap, mengelola aspirasi masyarakat umum kelurahan melalui rembug warga berbasis partisipasi aktif dalam penanganan program penanggulangan kemiskinan menuju masyarakat mandiri, sejahtera dan berdaya melalui program pemberdayaan masyarakat yang ada dan kegiatan program kebijakan Pemerintah Kota/Kelurahan. Pengembangan, pengokohan dan pemampuan kelembagaan yang dilakukan dapat dilihat dari indikator, kemampuan BKM dalam menubuhkan kerjasama dan kepercayaan di internal BKM, kemampuan BKM untuk menumbuhkan kerjasama dan kepercayaan antara BKM dengan Masyarakat atau eksternal BKM, kemampuan BKM untuk memotivasi warga dalam melakukan pembangunan (peran BKM sebagai Agent of social change) kemampuan BKM menjalin kemitraan pihak luar.

LPMK Kelurahan Muktiharjo Kidul merupakan sebuah lembaga yang bertugas memberdayakan masyarakat ditingkat kelurahan diberbagai bidang. LPMK membantu 
kelurahan dalam memajukan masyarakat kelurahan, memberdayakan SDM ditingkat kelurahan, membuat pemetakan demografi social dan kerohanian tingkat kelurahan, menampung aspirasi masyarakat kelurahan melalui RW, membantu Pemerintah Kelurahan mencari solusi/ pemecahan masalah yang berkembang dimasyarakat kelurahan. LPMK belum optimal dalam membantu kelurahan dalam memajukan masyarakat kelurahan, memberdayakan SDM ditingkat kelurahan, membuat pemetakan demografi sosial dan kerohanian tingkat kelurahan, menampung aspirasi masyarakat kelurahan. Karena peran LPMK Kelurahan Muktiharjo Kidul belum optimal dalam melaksanakan tugas fungsinya.

Peran gerakan PKK Kelurahan Muktiharjo Kidul telah dilakukan melalui 10 (sepuluh)

Program Pokok PKK, yaitu kegiatan Pengamalan Pancasila, Gotong Royong, Pangan, Sandang, Perumahan dan Tatalaksana Rumah Tangga, Pendidikan dan Keterampilan, Kesehatan, Pengembangan Kehidupan Berkoperasi, Kelestarian Lingkungan Lingkungan Hidup, dan Perencanaan Sehat.

\section{DAFTAR REFERENSI}

Abdurarhaman Mustofa dan Soekartawi., Masalah Pengembangan Kelembagaan Pedesaan Dalam Rangka Pengentasan Kemiskinan. Makalah., tt,tth. 1999

Anselm Strauss \& Juliet Corbin. Basics of Qualitatif Research Cetakan Pertama, Juli 2003 PP.2003.38

Arif, Syaiful,. Menolak Pembangunanisme. Pustaka Pelajar, Yogjakarta, 2000

Bakhit, Izzadin et. all, Attacking The Roots of Poverty, Yakoma-PGI, Jakarta,1996

Bambang Rudito. Arif Budimanta, Metode dan Teknik Pengelolaan Community Development Cetakan Pertama. ICSD \& FKPM, 2003

Bintarto, interaksi Desa-Kota dan Permasalahannya, Ghalia Indonesia, Jakarta ,1989

Chambers, Robert, People : From Impoverishment to Empowerment, New York University Press 1995 Fandy Tjiptono, Manajemen jasa, Andi Offset, Yogyakarta, 1996.

Gunawan Sumodiningrat (1997). Pembngunan Daerah dan pemberdayaan Masyarakat ,PT Bina Rena Pariwara, jakarta

Gunawan Sumodiningrat (1999),Agenda Pemulihan Ekonomi, Mewujudkan Kesejahteraan Rakyat melalui pemberdayaan dan otonomi daerah ,Kipas Putih Aksara, Jakarta

Gunawan Sumodiningrat (2009) (editor : Aribowo Suprajitno Adhi). Mewujudkan Kesejahteraan 
Bangsan,Menanggulangi Kemiskinan dengan prinsip Pemberdayaan Masyarakat, PT Elex Media Komputindo /Gramedia, Jakarta

Kartsasmita, Ginanjar; Pembangunan Untuk Rakyat, SIDES, Jakarta, 1996.

Koenjaraningrat, Metode-metode Penelitia Masyarakat, Gramedia, Jakarta, 1980.

Korten, DC., 1988, Community Organization and Rural Development ; A Learning Pricces Approach Publik Administration Review, Vol 40, No 5, Sept - Oktober : 480 - 511

Long, N.. Sosiologi Pembangunan Pedesaan, Bina Aksara, Jakarta. 1992

Matthew B. Miles \& Michael Huberman. Qualitative Data Analysis. Cetakan Pertama, Universitas Indonesia. Salemba 4. Jakarta. 1992

Nasikun, Dr, Urbanisasi dan Kemiskinan di Dunia Ketiga, PT Tiara Wacana Jakarta,1996

Nurdin Widodo Dan Suradi. Penelitian Profil Dan Peranan Organisasi Lokal Dalam Pembangunan Masyarakat.

Oos M. Anwas, Pemberdayaan Masyarakat di Era Global, Alfabeta, Bandung, 2013

Siahaan, H.M. 1993. Dimensi Struktural don Kultural Kemiskinan Pedesaan Surabaya Post, Senin, 3 Maret 1993.

Sondang P.Siagian, Prof,Dr, Filsafat Administrasi, Gunung Agung ,Jakarta, 1995

Suharsimi Arikunto. Prosedur Penelitian, Suatu Pendekatan Praktek edisi revisi V. Jakarta Nov 2002.

Suharto Edi, Makalah Pembangunan Kesejahteraan Sosial dalam Pusaran Desentralisasi dan Good

Governance, Balai Besar Pendidikan dan Pelatihan Kesejahteraan Sosial (BBPPKS)

Banjarmasin, 21 Maret 2006.

Sumodiningrat, Gunawan dkk.; Kemiskinan Teori Fakta dan Kebijakan, Impac, Jakarta,

The Liang Gie, Keadilan sebagai Landasan bagi Administrasi Pemerintahan dalam Negara Republik Indonesia, Liberty, Yogyakarta, 1993.

Todaro, P Michael, Economic Development Seventh Edition Pearson Education Limited. 2000.

Totok Mardikato, Model-Model Pemberdayaan Masyarakat, Sebelas Maret University Press, Surakarta, 2013

Uphoff Norman., Local Instututional Development: An Analytical Source Book With Cases, Rural Development Committee, Cornell University. 1986.

DPU,Ditjen Cipta Karya ( 2009 ),Pedoman Pelaksanaan PNPM Mandiri Perkotaan,Jakarta DPU,Ditjen Cipta Karya (2008-2010) ,Modul-modul Pelatihan Pemberdayaan Masyarakat, TOT Pemandu Nasional PNPM Mandiri Perkotaan,Jakarta

Komite Penanggulangan Kemiskinan, Strategi Nasional Penanggulangan Kemiskinan. Jakarta. September 2005 
Kep. Mendagri No. 411.4-401 tahun 2005 tentang PKK

Peraturan Mensos No 83/HUK/2005 tentang Karang Taruna

Perda No. 4 th. 2009 tentang Lembaga Kemasyarakatan Kelurahan Kota Semarang.

PP Nomer 72 Tahun 2005 tentang BPD

PP Nomer 73 Tahun 2005 tentang LPM

Proyek Penanggulangan Kemiskinan di Perkotaan, Buku Pedoman Teknis P2KP 1 Tahap 2. Jakarta

Proyek Penanggulangan Kemiskinan di Perkotaan, Buku Pedoman Umum cetakan pertama. Jakarta September 2004

UU No. 23 th.2014 tentang Pemerintah Daerah. 